Original Article

\title{
Introgression of bacterial leaf blight (BLB) resistant gene, Xa7 into MARDI elite variety, MR219 by marker assisted backcrossing (MABC) approach
}

\author{
Introdução do gene resistente à ferragem da folha bacteriana (BLB), xa7 na variedade \\ MARDI elite, MR219 por abordagem de backcrossing assistida por marcador (MABC)
}

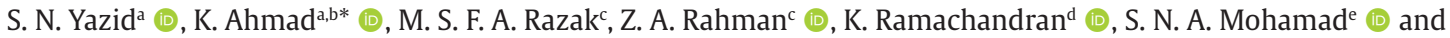 \\ M. B. AB Ghaffar ${ }^{\text {** }}$ (D) \\ aUniversiti Putra Malaysia - UPM, Faculty of Agriculture, Department of Plant Protection, Serdang, Selangor, Malaysia \\ bUniversiti Putra Malaysia - UPM, Institute of Tropical Agriculture and Food Security - ITAFoS, Serdang, Selangor, Malaysia \\ 'Malaysia Agricultural Research and Development Institute - MARDI, Centre for Marker Discovery and Validation - CMDV, Serdang, Selangor, \\ Malaysia \\ ${ }^{\mathrm{d}}$ Malaysia Agricultural Research and Development Institute - MARDI, Paddy and Rice Research Centre, Kepala Batas, Pulau Pinang, Malaysia \\ eUniversiti Sains Malaysia, School of Biological Science, Penang, Malaysia \\ ${ }_{\mathrm{f}}^{\mathrm{f}}$ Malaysia Agricultural Research and Development Institute - MARDI, Industrial Crop Research Centre, Kepala Batas, Pulau Pinang, Malaysia
}

\begin{abstract}
Bacterial leaf blight (BLB) is one of the major rice diseases in Malaysia. This disease causes substantial yield loss as high as 70\%. Development of rice varieties which inherited BLB resistant traits is a crucial approach to promote and sustain rice industry in Malaysia. Hence, this study aims were to enhance BLB disease resistant characters of high yielding commercial variety MR219 through backcross breeding approach with supporting tool of markerassisted selection (MAS). Broad spectrum BLB resistance gene, Xa7 from donor parent IRBB7 were introgressed into the susceptible MR219 (recurrent parent) using two flanking markers ID7 and ID15. $\mathrm{At}_{\mathrm{BC}} \mathrm{F}_{4}$, we managed to generate 19 introgressed lines with homozygous Xa7 gene and showed resistant characteristics as donor parent when it was challenged with Xanthomonas oryzae pv. oryzae through artificial inoculation. Recurrent parent MR219 and control variety, MR263 were found to be severely infected by the disease. The improved lines exhibited similar morphological and yield performance characters as to the elite variety, MR219. Two lines, PB-2-107 and PB-2-34 were chosen to be potential lines because of their outstanding performances compared to parent, MR219. This study demonstrates a success story of MAS application in development of improved disease resistance lines of rice against BLB disease.
\end{abstract}

Keywords: Oryza sativa L., backcrossing, marker assisted selection, Xa7 gene, bacterial leaf blight.

\begin{abstract}
Resumo
A mancha bacteriana das folhas (BLB) é uma das principais doenças do arroz na Malásia. Essa doença causa perdas substanciais de rendimento de até 70\%. O desenvolvimento de variedades de arroz que herdaram características de resistência ao BLB é uma abordagem crucial para promover e sustentar a indústria do arroz na Malásia. Portanto, o objetivo deste estudo foi aumentar os caracteres BLB resistentes a doenças da variedade comercial MR219 de alto rendimento por meio de uma abordagem de cruzamento retrocruzamento com ferramenta de apoio de seleção assistida por marcador (MAS). O gene de resistência a BLB de amplo espectro, Xa7 do pai doador IRBB7, foi introgressado no MR219 suscetível (pai recorrente) usando dois marcadores flanqueadores ID7 e ID15. No BC3F4, conseguimos gerar 19 linhagens introgressadas com o gene Xa7 homozigoto e apresentamos características de resistência como genitor doador quando desafiado com Xanthomonas oryzae pv. oryzae por inoculação artificial. O pai recorrente MR219 e a variedade controle, MR263, estavam gravemente infectados pela doença. As linhas melhoradas exibiram características morfológicas e de desempenho de rendimento semelhantes às da variedade elite, MR219. Duas linhas, PB-2-107 e PB-2-34, foram escolhidas como linhas potenciais por causa de seus desempenhos excelentes em comparação com a mãe, MR219. Este estudo demonstra uma história de sucesso de aplicação de MAS no desenvolvimento de linhas de arroz melhoradas com resistência a doenças contra a doença BLB.
\end{abstract}

Palavras-chave: Oryza sativa L., retrocruzamento, seleção assistida por marcadores, gene Xa7, mancha bacteriana das folhas.

*e-mail: Khairulmazmi@upm.edu.my; bahagia@mardi.gov.my

Received: February 3, 2021 - Accepted: July 9, 2021 


\section{Introduction}

Rice (Oryza sativa L.) is always known to be at the frontline to tackle world hunger, as it is the second most widely grown cereal crop in the world (Siwar et al., 2014). About 3.5 billion world population are relying on rice as their main source of energy (Majumder et al., 2019). Regrettably, the global trend of rice production in 2020 will represent a decrease trend compare to previous production year (USDA, 2020). Malaysia constitutes only $0.37 \%$ of the total world rice production, which covers $72 \%$ of the national self-sufficiency level (KR Institute, 2019; USDA, 2020). MR219 is the major contributor to this number since $>90 \%$ of Malaysia's granary areas were planted with this popular variety due to its high yielding character with $8319 \mathrm{~kg}$ ha $^{-1}$ heaviest yield has ever reported (Elixon et al., 2017; Shamsudin et al., 2016). However, this production size is openly threatening to $30-50 \%$ losses by means of bacterial leaf blight (BLB) disease infection (Shamsudin et al., 2019). A known pathogenic bacterial-borne disease caused by Xanthomonas oryzae pv. oryzae (Xoo) (Chukwu et al., 2019). The disease has become devastating to rice for ages since it was first discovered by a Japanese in 1884 (Tagami and Mizukami, 1962).

Malaysia's tropic humid weather with continuity shade, flood and rain throughout the year favored Xoo infection. These conditions availing bacterium transmission through the splashing or windblown rain, plant to plant contact, and irrigation of water. In rice production, Xoo invasion occurred via wound cells caused by root development or injuries transpired during handling, insect attack, or through natural openings like hydathodes and stomata. The established infection leads to noticeable lesions on leaf surface which reduce the green leaf area resulting to reduce photosynthesis rate, blockage of water supply, and increase transpiration plant (Saha et al., 2015; Wurff et al., 2016). Later, promoted cell death and desiccation of dying tissue (Lindenthal et al., 2005). Despites, management of BLB in the field is made feasible using several methods like agrochemical sprays, biological control, and cultural practices. But, none of them are found to be cost-effective and environmentally sound (Bhandari, 2014; Khan et al., 2012; Noda et al., 2001). Moreover, studies have aroused biological concern since excessive use of agrochemicals in large cultivation of $\mathrm{N}$ responsive rice varieties has the capability to rapidly induce pathogens to be more virulent against pesticides over times (Bhandari, 2014). The use of resistance rice as was introduced by the Malaysian Agricultural Research and Development Institute (MARDI) is seemed to be the most effective approach to overcome the issue in the field.

Improvement of rice resistance by introgressing BLB resistance gene, Xa7 from isoline IRBB7 into elite MR219 using marker assisted backcrossing technique is a fast breeding strategy. Recently, experimental results have shown that more than 42 resistance $(R)$ genes conferring rice resistance to various strains of $X o o$ have been identified. Among them, 11 R-genes were cloned, namely Xa1, Xa3/ Xa26, Xa4, xa5, Xa10, xa13, Xa21, Xa23, xa25, Xa27, and Xa41 (Chukwu et al., 2019; Ji et al., 2018; Jiang et al., 2020). Dominant and recessive gene of BLB resistance R-gene were denoted as big and small capital letter, respectively. IRBB7, an advanced rice variety harboring the dominant gene, $\mathrm{Xa7}$ gene was developed through gene transferred from originated rice cultivar DV85 into 'IR24' (Chukwu et al., 2019). The gene has fine mapped to be located at interval of approximately $118.5 \mathrm{~kb}$ on chromosome 6 (Khan et al., 2012). Xa7 has potential value in rice breeding programs because of broad-spectrum character against various Xoo strains and has fitness penalty in Xoo associated with adaptation to Xa7 (Jiang et al., 2020; Zhang et al., 2009). The gene is suitable to be employed into rice varieties in Malaysia that usually experiencing temperature highs around $32-33{ }^{\circ} \mathrm{C}$. For, the care of $\mathrm{Xa7}$ is more effective at high temperatures compared to other BLB resistance genes which are found to be less effective (Jiang et al., 2020; Webb et al., 2010). MAS using molecular marker, simple tagged sequences (STSs) is beneficial to accelerate the backcrossing process by reducing the number of backcrosses required to recover the recurrent phenotype. Chen et al. (2000) first reported a successful record of BLB resistance gene introgression for rice using combination both conventional and molecular into Chinese hybrid rice parents representing as a positive feedback to these approaches (Hasan et al., 2015; Chen et al., 2008).

Therefore, the best attempts to develop resistant rice variety is by incorporating BLB-resistance genes through both backcross breeding technique and molecular marker tools, maker-assisted selection (MAS). These approaches permitting the introgression of BLB resistant gene, Xa7 to induce host resistance and comes in handy for largescale plantation. Hence, the objectives of this study were to validate the presence of the $\mathrm{Xa7}$ gene introgressed in the $\mathrm{BC}_{3} \mathrm{~F}_{3}$ lines using a marker-assisted selection of closed-linked STS markers ID7 and ID15, to evaluate the disease-resistant performance of the improved MR219 lines against $\mathrm{Xoo}$ and to assess the agronomic performance of the improved MR219 lines in the field.

\section{Materials and Methods}

\subsection{Pure culture of Xoo and evaluation of parents' resistance level}

The pure culture of $X$. oryzae pv. oryzae-severe strain was obtained from the Culture Collection Unit of MARDI Seberang Perai, Pulau Pinang. The Xoo colony of 72-hr old culture was then diluted in $5 \mathrm{~mL}$ of sterile distilled water to attain at concentration of $10^{9} \mathrm{cfu} / \mathrm{mL}$ for artificial inoculation. The inoculation on to IRBB77, MR263, MR220-CL2 and MR219 were carried out in September 2018 to November 2018 by adoption of the leaf clipping technique as was described by Mew et al., (1982). The tip of rice leaf ( 2 to $3 \mathrm{~cm}$ ) of 40-day old rice was cut with a scissors which was previously dipped into bacterial solution (Mew et al., 1982). In this study randomize completely block design with 5 plants for every 3 blocks. The experiment was conducted in a glasshouse. Inoculated leaves were evaluated at 3, 7, 14, 21 and 30 day after inoculation. The infected leaves were rated according to lesion length 
as described in the Standard Evaluation System for rice (INGER, 1996).

\subsection{Plant materials and backcrossing}

Plant material using IRBB7 (BLB-resistant) as donor parents, and MR219 (BLB-susceptible) as recurrent parent were chosen before initiated the backcrossing breeding program. The programmed (Figure 1) was started by crossing the MR219 with the donor parent IRBB7 to produce the first filial generation ( $F_{1}$ seed). The $F_{1}$ female parent were then backcrossed with the MR219 to produce the first backcross generation $\left(\mathrm{BC}_{1} \mathrm{~F}_{1}\right)$. Marker assisted selection (MAS) was utilized to tag $X a 7$ gene through two STS markers; ID7 and ID15 which was reported to have closed-linked to Xa7 R-gene (Zhang et al., 2009). Only individual contain $\mathrm{Xa}$ 7 were selected and the other were discarded. Selected $\mathrm{BC}_{1} \mathrm{~F}_{1}$ plants were then backcrossed again with recurrent parent MR219 to produce the $\mathrm{BC}_{2} \mathrm{~F}_{1}$ generation. Subsequent backcross populations were made by backcrossing the selected backcross $\mathrm{BC}_{2} \mathrm{~F}_{1}$ plants with the MR219 to produce $\mathrm{BC}_{3} \mathrm{~F}_{1}$. It should be emphasized that backcross progeny must be selected based on $\mathrm{Xa7}$ gene targeted allele and phenotypic performance with closeness recovery to the recurrent parent, MR219 during each round of backcrossing. After the final backcross generation, selected $\mathrm{BC}_{3} \mathrm{~F}_{1}$ individuals with $\mathrm{Xa}$ R R-gene were allowed to self-pollinated up to $\mathrm{BC}_{3} \mathrm{~F}_{4}$ progenies so that selected lines will be homozygous to the target $X a 7$ gene. Nineteen improved lines homozygous for IRBB7 allele in the Xa7 gene targeted regions and two improved lines homozygous for MR219 alleles in non-targeted regions were established in this study.

\subsection{Plant DNA isolation and molecular analysis}

The plant leaves materials were harvested at young stage and stored in a $-20^{\circ} \mathrm{C}$ deep freezer for long-term storage. The plant materials were then further to DNA extraction using Taco ${ }^{\mathrm{TM}}$ plant DNA/RNA extraction kits (GeneReach, Taiwan). The extracted DNA was diluted to $50 \%$ with elution buffer before polymerase chain reaction (PCR). The PCR reaction mixture ( $10 \mu \mathrm{l})$ containing $1 \mu \mathrm{l}$ of $50 \mathrm{ng} / \mu \mathrm{l}$ DNA template, $1 \mu \mathrm{l} 10 \mathrm{x}$ buffer, $1 \mu \mathrm{l}$ of dNTPs, $0.5 \mu \mathrm{l}$ of $25 \mathrm{mM} \mathrm{MgCl}, 6 \mu \mathrm{l}$ of nucleus-free water, $0.1 \mu \mathrm{l}$ of taq DNA polymerase and $0.4 \mu \mathrm{l}$ of $10 \mu \mathrm{M}$ for each forward and reverse primers were prepared. Established STS marker ID7 (forward primer: 5'-ATATTCACCAAATGATTCCCTG -3'; reverse primer: 5'- ATACAAGCCTAAACCCATCTC A -3') and ID15 (forward primer: 5'-ATACAGTGCCAATGATGAGGAG-3'; reverse primer: 5'-CATACGAAACCCAACAGAAATAG-3') were utilized to check $X a 7$ allelism in $\mathrm{BC}_{3} \mathrm{~F}_{3}$ population. The PCR products were then fractionated in $2 \%$ agarose gels by electrophoresing at $80 \mathrm{~V}$ for $45 \mathrm{~min}$ in TBE buffer. Then, the gel was photographed under ultraviolet light.

\subsection{Evaluation of agronomic traits in the field}

The field evaluation was carried out in experimental plot at MARDI, Seberang Perai during the main season

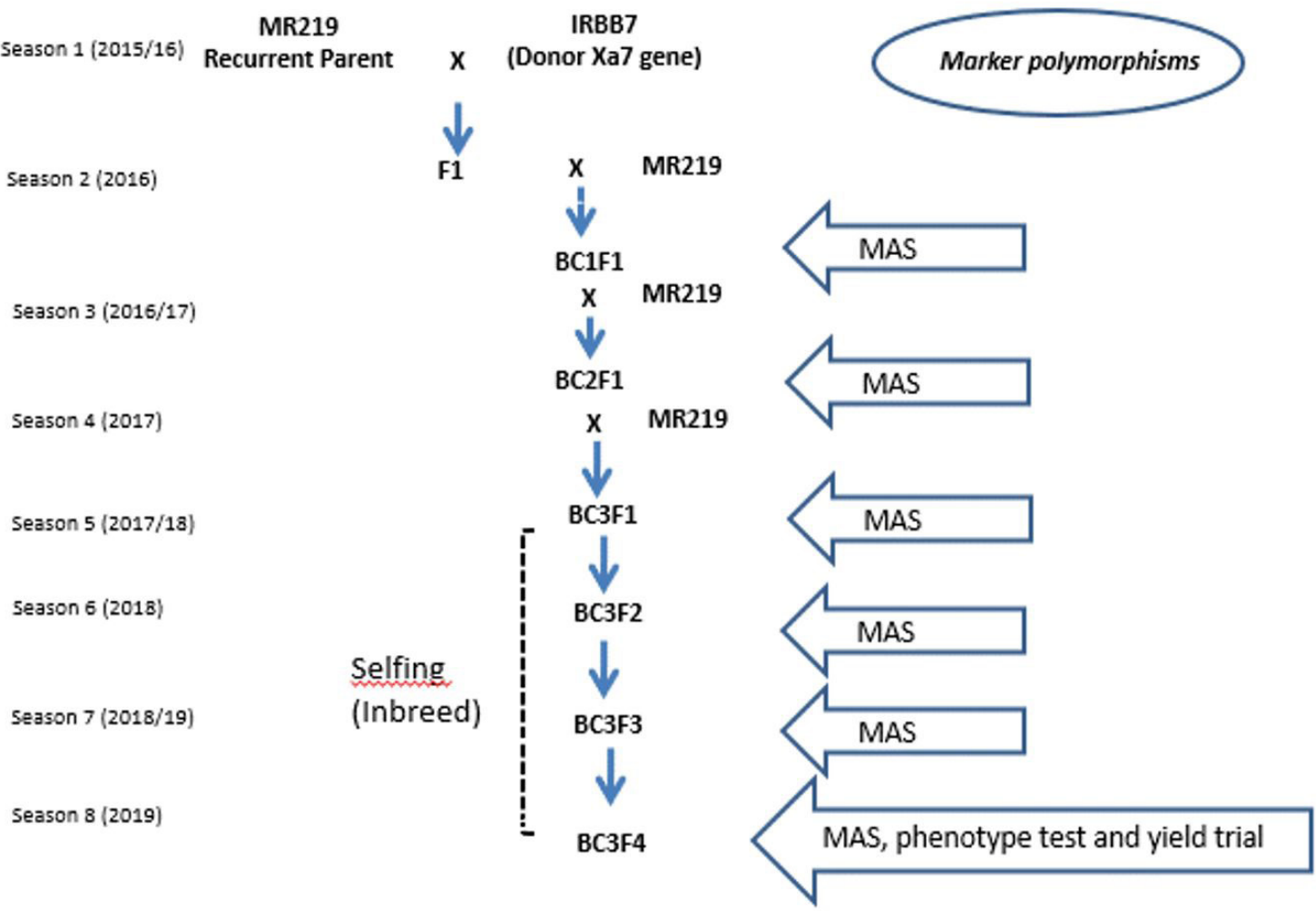

Figure 1. Backcrossing program used in this study to develop improved lines of rice $\left(\mathrm{BC}_{3} \mathrm{~F}_{4}\right)$. 
from November 2018 to January 2019. The 20-25 days old selected $\mathrm{BC}_{3} \mathrm{~F}_{4}$ seedlings plants were transplanted as single seedling per hill. Randomized completely block design (RCBD) with three replicates was used in this study. The plot size was $4 \mathrm{~m} \times 4 \mathrm{~m}$, with $0.25 \mathrm{~m} \times 0.25 \mathrm{~m}$ per planting distance for each tested material. The crops were fertilized with 100:75:103 kg/ha of $\mathrm{N}, \mathrm{P}_{2} \mathrm{O}_{5}, \mathrm{~K}_{2} \mathrm{O}$. Nine agronomic traits were evaluated according to the Standard Evaluation System of rice (IRRI, 2013). The traits investigated comprised number of tillers, plant height $(\mathrm{cm})$, leaf length $(\mathrm{cm})$, days to $50 \%$ heading (days), days to $80 \%$ maturation (days), panicle length (cm), filled spikelet per panicle (\%), weight of 1000 -grains $(\mathrm{g})$ and yield $(\mathrm{kg} / \mathrm{ha})$.

\subsection{Assessment of BLB disease resistance of rice progenies}

All 21 potential lines and parents (MR219 and IRBB7) were tested for host reaction in a glasshouse at MARDI Seberang Perai. The experiment was conducted from January 2019 to March 2019. The same procedure which used in earlier disease screening experiment on parents were also applied in this evaluation. The experiment was also used RCBD with three replicates. Each replicate contains 10 plants for each line and were grown in trough box in glasshouse. Lesion length $(\mathrm{cm})$ were recorded after 25 days of inoculation. The resistance level was categorized based on lesion length as follow: scale index were $1 \mathrm{~cm}$ $-5 \mathrm{~cm}=$ Resistant $-\mathrm{R},>5 \mathrm{~cm}-10 \mathrm{~cm}=$ Moderately Resistant MR; $>10-15 \mathrm{~cm}=$ Moderately Susceptible- MS, $>15 \mathrm{~cm}$ = Susceptible-S according to Standard Evaluation System of Rice (IRRI, 1988).

\subsection{Statistical analysis}

Data were subjected to analysis of variance (ANOVA) and the means were compared using Duncan's Multiple Range Test (DMRT) to test any difference of disease response to BLB and agronomic traits among the lines and parents. The disease response to BLB values of each line were averaged for 10 individuals. Meanwhile, agronomic traits for each line were averaged for 4 individuals. Statistical analysis was done using the Statistical Analysis System (SAS 9.4).

\section{Results}

\subsection{Selection of parental lines using host resistance evaluation}

Pathotype Xoo isolated from MARDI Seberang Perai were used in this pathogenicity screening on parental lines. The lesion length affected by BLB has been used as measurement for affected disease assessment. Data started recorded after day three of pathogen inoculation date (DAI) and was continued every two days interval over 30 days. The host reaction pattern of four potential parents of IRBB7, MR263, MR220-CL2 and MR219 after being inoculated with Xoo was summarized in Figure 2. From the obtained data, lesion length affected by BLB has shown that the disease was slowly developed after 5 days of disease inoculation (DAI). Comparison disease symptom between treated lines were particularly clear

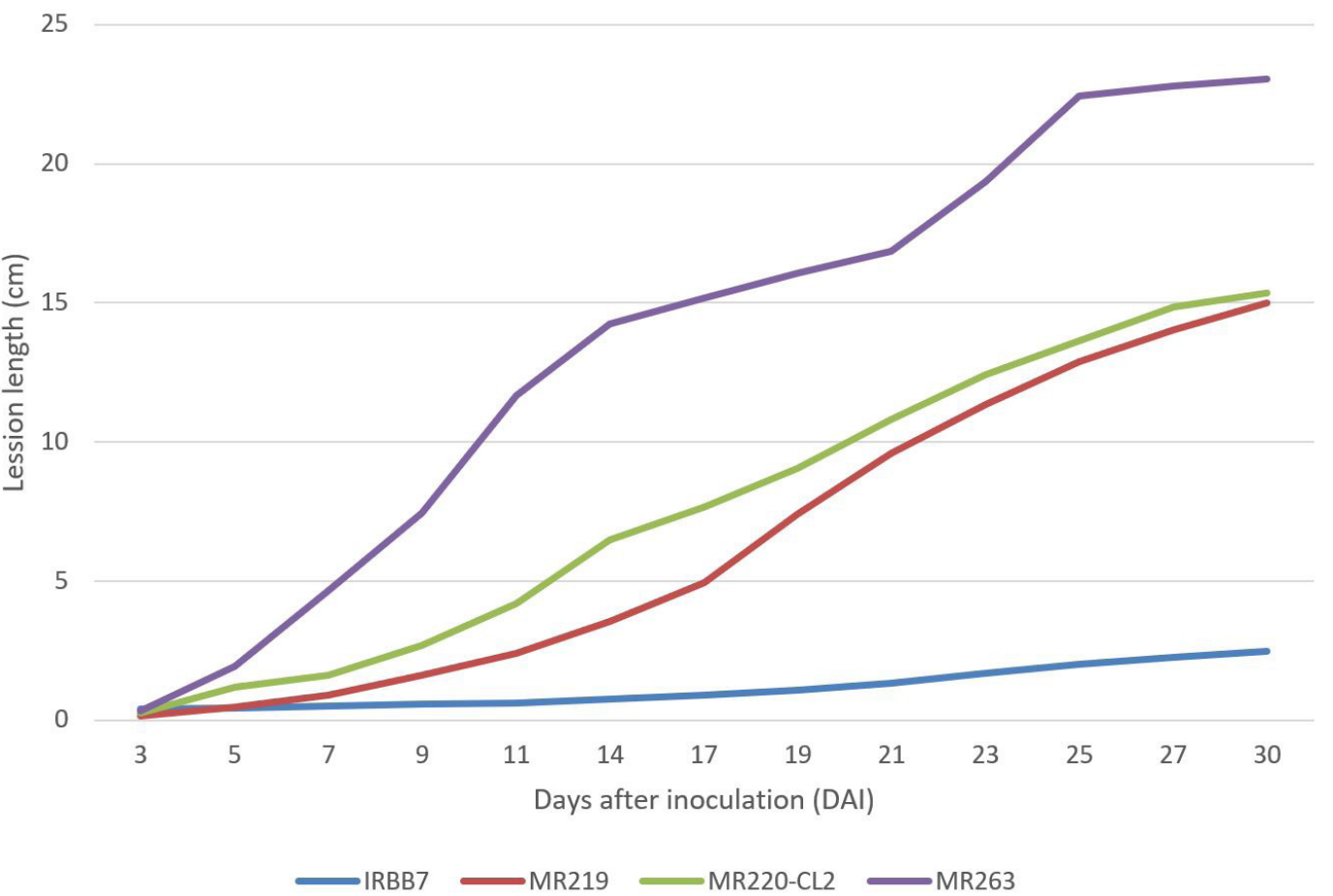

Figure 2. Bacterial leaf blight disease progression recorded on four potential parents; IRBB7 (blue), MR219 (orange), CL2 (gray) and MR219 (yellow) from 3 to 30 days after inoculation. 
at 7 DAI especially for susceptible control variety MR263. Lesion length of affected leaf have been recorded about $4.66 \pm 0.12 \mathrm{~cm}$ on variety MR263, almost double from the other varieties. After $25 \mathrm{DAI}$, the significant different showed even bigger. The lesion length for variety MR263 has reach optimum level about $22.44 \pm 0.40 \mathrm{~cm}$ and was classified as susceptible line. Variety MR219 and MR220CL2 are closed with data mean different of $1.21 \mathrm{~cm}$ in lesion length of affected leaf with recorded findings at $12.90 \pm 4.99 \mathrm{~cm}$ and $13.64 \pm 0.56 \mathrm{~cm}$ and both are considered as moderate susceptible (MS) category. In contrast, variety IRBB7, donor parent for Xa7 shows highly resistant character, only $1.99 \mathrm{~cm}$ of data mean disease lesion length was discovered even after 25 day. Figure 3 showed BLB symptoms on infected leaves but no disease symptom on IRBB7 after being inoculated with $X o o$-severe strain. Findings revealed that IRBB7 was the most resistant parents. And, it was followed

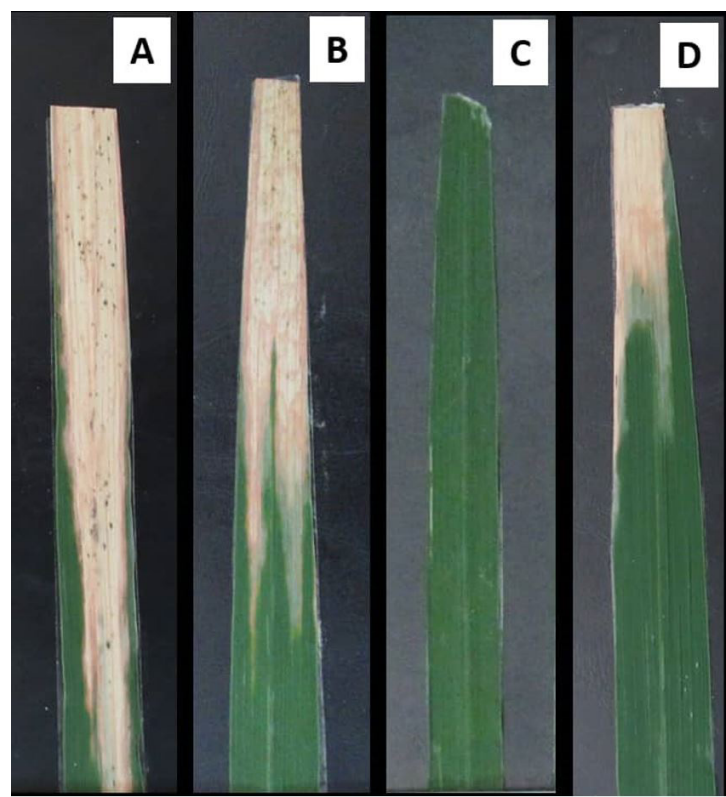

Figure 3. Differential response of parents. (A) MR263, (B) CL2, (C) IRBB7 and (D) MR219, respectively after being inoculated with Xanthomonas oryzae pv. oryzae at 14 DAI. by MR219> MR220-CL2 > MR263. This study is further confirmed that IRBB7 is resistant parents.

\subsection{Marker assisted selection analysis of Xa7 introgressed in $\mathrm{BC}_{3} \mathrm{~F}_{3}$ population}

Molecular findings of this study revealed the number of successful $\mathrm{BC}_{3} \mathrm{~F}_{3}$ population introgressed with $\mathrm{Xa7}$ using backcrossing and MAS (Figure 4). In the present study, $\mathrm{BC}_{3} \mathrm{~F}_{4}$ rice lines were analyzed for the presence and absence of the Xa7 using PCR based techniques. This analysis allows locating closely linked region to $\mathrm{Xa7}$ by identifying polymorphic amplification products between near-isogenic resistant (IRBB7) and susceptible parents (MR219). Validation using STS primers, ID7 and ID15 (tightly linked markers to resistant gene Xa7) were utilized. Results showed polymorphic fragmentation region for both markers were found between 653 bp and 449 bp respectively, which indicating successfully been incorporated with $\mathrm{Xa7}$ gene. Meanwhile, non-targeted allele of ID7 and ID15 were found at approximately 410bp and 414bp respectively, which indicating unsuccessfully been incorporated with $\mathrm{Xa7}$ gene. Finding revealed that all tested lines (1-19) showed positive band of Xa7. On the other hand, two lines i.e. PB-2-32 and PC3-5-2 showed negative result. Together, negative check variety, MR263 also showed negative result. The use of these markers showed clear polymorphism between the two parents indicating that there were 19 improved BC3F4 successfully been incorporated with $\mathrm{Xa} 7$ gene and 2 improved $\mathrm{BC}_{3} \mathrm{~F}_{4}$ were unsuccessfully been incorporated with $\mathrm{Xa7}$ gene.

\subsection{Evaluation of agronomic traits of improved lines at $\mathrm{BC}_{3} \mathrm{~F}_{4}$ generation}

The mean data on agronomic and yield performance of all 19 introgress lines, 2 lines without R-gene and potential parents were presented in Table 1 . The findings of the ANOVA study show significant differences in all measurement characteristics except for the total number of tillers, the length of the panicle and the weight of 1000 grains. Most of traits significant were came from the differentiation between donor IRBB7 and recurrent parent MR219. For example, Parent MR219 was the highest with

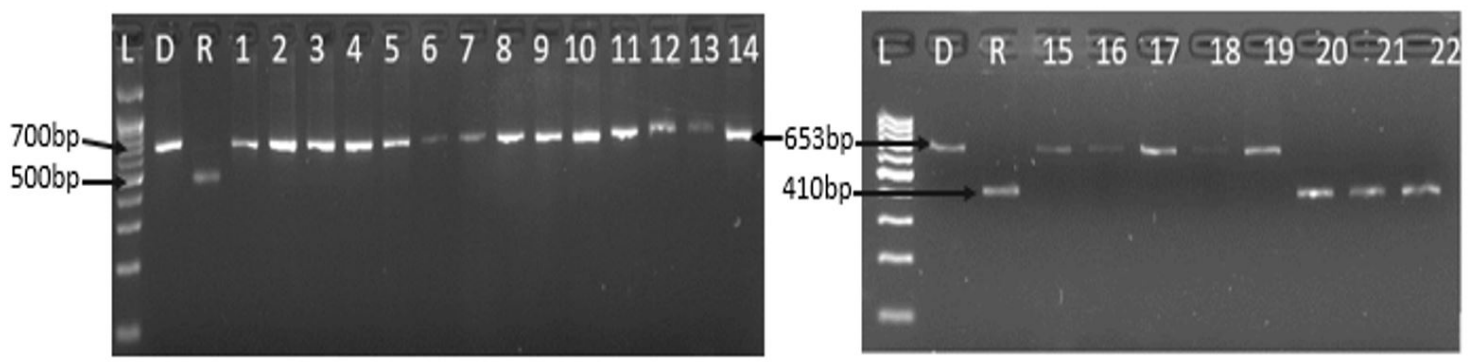

Figure 4. PCR-based genetic polymorphism analysis of Xa7 gene closed linked, ID7 marker. Agarose gel profile of backcrossed progenies in $2 \%(\mathrm{w} / \mathrm{v})$ of $1 \mathrm{X}$ TBE agarose gel. Lane L: 100bp DNA ladder. Lanes D and R represent IRBB7 and MR219 respectively. Line 1-22: (1) PB-2-91, (2) PB-2-107, (3) PB-2-156, (4) PB-2-224, (5) PB-2-234, (6) PB-2-238, (7) PB-2-258, (8) PB-2-29, (9) PB-2-77, (10) PB-2-226, (11) PC3-26-2, (12) PC-39-3, (13) PB-2-34, (14) PB-2-35, (15) PB-2-150, (16) PB-2-223, (17) PB-2-252, (18) PC-3-14-3, (19) PC-3-23-1, (20) PB-2-32, (21) PC3-5-2, (22) MR263. 


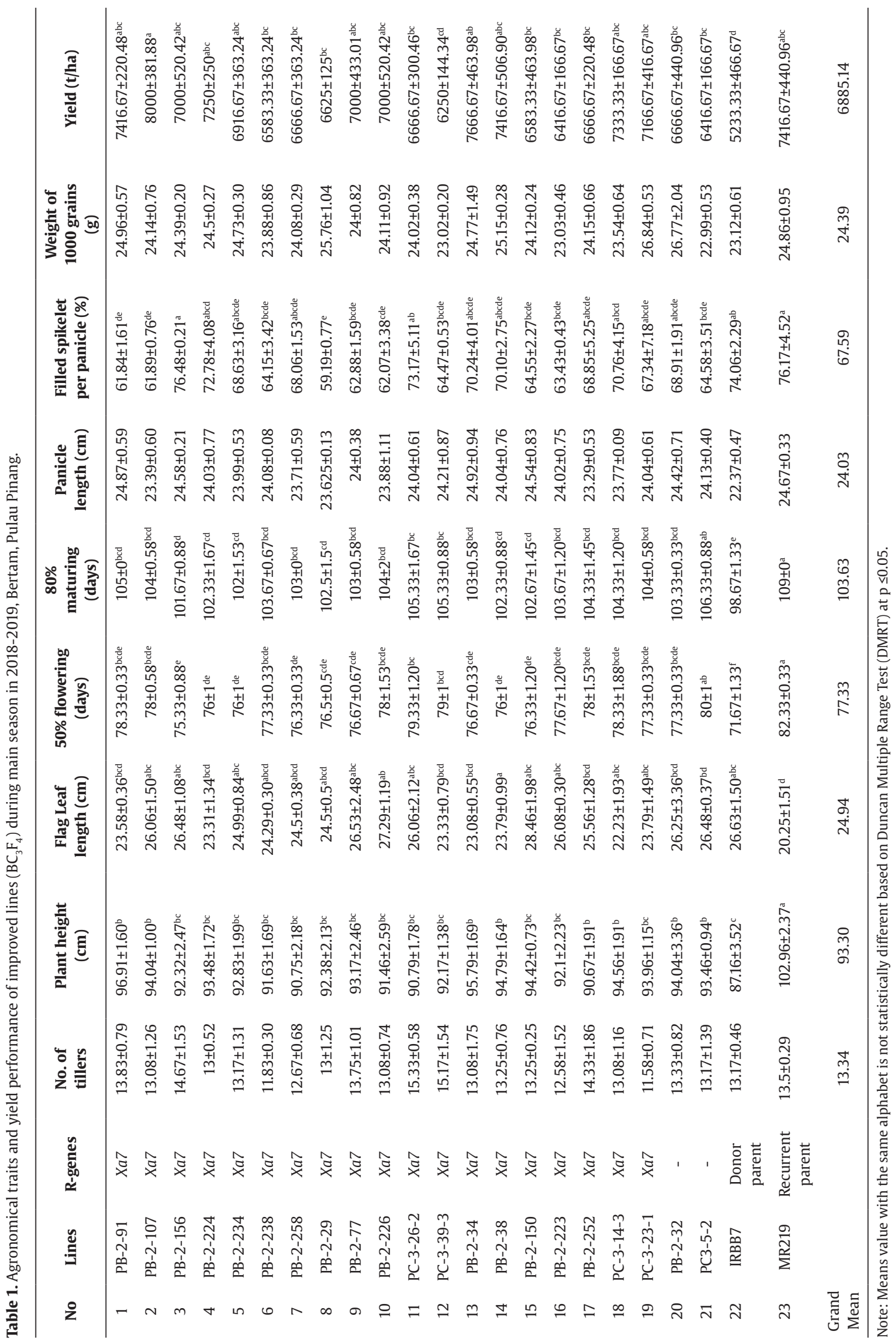


$102.96 \mathrm{~cm}$ plant height and donor IRBB7 was the shortest at $87.16 \mathrm{~cm}$ height. MR219 also has the longest flowering and maturity date at 71.67 and 109 days after sowing, respectively. IRBB7 also produced the lowest yield with only $5233.33 \mathrm{~kg} /$ ha compared with parent MR219 at $7416.67 \mathrm{~kg} /$ ha. In contrast, MR219 have the shortest length of flag leaf with only $20.25 \mathrm{~cm}$ which is special characteristic of this variety. For 21 improved lines including two lines without Xa7 gene, results comparison shows that the majorities were good as recurrent parent MR219. Most of measurement were in the middle between both parents. The range of the plant height were between $90.67-96.91 \mathrm{~cm}$, trait for $50 \%$ flowering days were range between $75.3-80$ days and $80 \%$ maturity were between 101.67 to 106.33 days. Whist, for yield performance, all 21 improved lines were found no statistically different with recurrent parent MR219. Interestingly, two lines shows better yield than recurrent parent MR219 such as line PB-2-91, the highest with $8000 \mathrm{~kg} /$ ha and lines PB-2-34 at $7666.7 \mathrm{~kg} / \mathrm{ha}$.

\section{4. $B C_{3} F_{4}$ disease evaluation against Xanthomonas oryzae pv. oryzae}

The efficacy of R-gene, Xa7 introgressed into the $\mathrm{BC}_{3} \mathrm{~F}_{4}$ lines was evaluated by challenged them with
Xoo-severe strain. The results revealed that recurrent parent MR219 and susceptible check variety MR263 were found severely affected by the disease (Table 2). Both varieties recorded with lesion length of $>15 \mathrm{~cm}$ which indicating that they were susceptible (S). Similar result was noted on the two $\mathrm{BC}_{3} \mathrm{~F}_{4}$ lines without $\mathrm{Xa7}$ gene, $\mathrm{PB}-2-32$ and $\mathrm{PC} 3-5-2$. On the other hand, donor parent, IRBB7 showed highly resistant characteristic. It recorded the lowest lesion length $(0.7 \pm 0.18 \mathrm{~cm})$. Similarly, all 19 introgressed $\mathrm{BC}_{3} \mathrm{~F}_{4}$ lines shows closely similar disease resistant pattern as donor parent, IRBB7. Thus, donor IRBB7 and all 19 introgressed lines were grouped in resistant $(\mathrm{R})$ group.

\section{Discussion}

The use of molecular marker in breeding program is a powerful tool for tagging of gene regions which is not available in traditional plant breeding technique (Prioul et al., 1997). The markers could have linked to specific traits of the plant would allow plant breeders to identify character of interest and make their selection. This exercise is called marker assisted selection (MAS), and it can also help to monitor the transfer of desirable genes from one plant to another such as from parents to their

Table 2. Lesion length and response of improve lines $\left(\mathrm{BC}_{3} \mathrm{~F}_{4}\right)$ recorded after 25-days after inoculation with Xanthomonas oryzae pv. Oryzae.

\begin{tabular}{|c|c|c|c|c|}
\hline No. & Lines & R-gene & Lesion length $(\mathrm{cm})$ & Descriptions \\
\hline 1 & PB-2-91 & Xa7 & $2.23 \pm 0.57^{d}$ & $\mathrm{R}$ \\
\hline 2 & PB-2-107 & Xa7 & $2.70 \pm 0.91^{\mathrm{d}}$ & $\mathrm{R}$ \\
\hline 3 & PB-2-156 & Xa7 & $1.86 \pm 0.63^{\mathrm{d}}$ & $\mathrm{R}$ \\
\hline 4 & PB-2-224 & Xa7 & $2.14 \pm 0.50^{\mathrm{d}}$ & $\mathrm{R}$ \\
\hline 5 & PB-2-234 & Xa7 & $2.74 \pm 1.07^{\mathrm{d}}$ & $\mathrm{R}$ \\
\hline 6 & PB-2-238 & Xa7 & $1.24 \pm 0.45^{\mathrm{d}}$ & $\mathrm{R}$ \\
\hline 7 & PB-2-258 & Xa7 & $1.74 \pm 0.47^{\mathrm{d}}$ & $\mathrm{R}$ \\
\hline 8 & PB-2-29 & Xa7 & $2.19 \pm 0.77^{d}$ & $\mathrm{R}$ \\
\hline 9 & PB-2-77 & Xa7 & $2.30 \pm 0.83^{d}$ & $\mathrm{R}$ \\
\hline 10 & PB-2-226 & Xa7 & $1.96 \pm 0.53^{\mathrm{d}}$ & $\mathrm{R}$ \\
\hline 11 & PC-3-26-2 & Xa7 & $1.93 \pm 0.49^{\text {ed }}$ & $\mathrm{R}$ \\
\hline 12 & PC-3-39-3 & Xa7 & $1.69 \pm 0.74^{\mathrm{d}}$ & $\mathrm{R}$ \\
\hline 13 & PB-2-34 & Xa7 & $2.61 \pm 1.48^{\mathrm{d}}$ & $\mathrm{R}$ \\
\hline 14 & PB-2-38 & Xa7 & $2.50 \pm 1.00^{\mathrm{d}}$ & $\mathrm{R}$ \\
\hline 15 & PB-2-150 & Xa7 & $1.43 \pm 0.23^{\mathrm{d}}$ & $\mathrm{R}$ \\
\hline 16 & PB-2-223 & Xa7 & $2.30 \pm 0.30^{\mathrm{d}}$ & $\mathrm{R}$ \\
\hline 17 & PB-2-252 & Xa7 & $0.76 \pm 0.23^{\mathrm{d}}$ & $\mathrm{R}$ \\
\hline 18 & PC-3-14-3 & Xa7 & $1.16 \pm 0.13^{d}$ & $\mathrm{R}$ \\
\hline 19 & PC-3-23-1 & Xa7 & $1.79 \pm 0.37^{\mathrm{d}}$ & $\mathrm{R}$ \\
\hline 20 & PB-2-32 & - & $12.89 \pm 0.46^{c}$ & MS \\
\hline 21 & PC3-5-2 & - & $12.38 \pm 0.07^{c}$ & MS \\
\hline 22 & IRBB7 & Donor parent & $0.7 \pm 0.18^{\mathrm{d}}$ & $\mathrm{R}$ \\
\hline 23 & MR219 & Recurrent parent & $16.46 \pm 1.21^{\mathrm{b}}$ & S \\
\hline 24 & MR263 & Negative & $18.44 \pm 2.21^{\mathrm{a}}$ & S \\
\hline Grand Mean & & & 4.146142 & \\
\hline
\end{tabular}

Note: R: Resistant; MR: Moderately resistant; MS: Moderately Susceptible; S: susceptible. Means value with the same alphabet is not statistically different based on Duncan Multiple Range Test (DMRT) at $p \leq 0.05$. 
progeny. Based on these advantages, we utilized MAS as support tools in our rice breeding program. We used this approach to introgress resistant gene, $\mathrm{Xa7}$ into our elite rice variety, MR219 to improve resistant characteristic against bacterial leaf blight (BLB) disease attacked. This BLB was classified as one of the major diseases rice in Malaysia which caused by pathogen, Xanthomonas oryzae pv. oryzae (Xoo) (Chukwu et al., 2019). The infection plant could reduce the yield of rice to $30-50 \%$ (Shamsudin et al., 2019), especially when the disease was attacked early in the tiller stage.

So far, there was no commercial rice variety in Malaysia has found to be resistant against the BLB disease (Chukwu et al., 2019). Therefore, major aim of the present study was to produce resistant rice variety for sustaining rice production in Malaysia. This resistance gene, Xa7 was chosen because it was proven to have a durable resistance gene against BLB (Chen et al., 2008; Vera Cruz et al., 2000). It is also a dominant resistance gene and was firstly identified in the rice cultivar DV85 (International Rice Research Institute accession number 8839) (Chen et al., 2008; Sidhu et al., 1978). To date, the Xa7 gene of DV85 has already been transferred to cv.IR24, and the near isogenic line (NIL) IRBB7 with Xa7 was developed by backcross with cv. IR24 as a recurrent parent (Ogawa et al., 1991).

In this study, the resistant level of $\mathrm{Xa7}$ gene was validated by challenging the potential donor parents, IRBB7 with Xoo-severe strain through artificial inoculation. It is very important experiment because confirmation need to done not only to make sure Xa7 gene is function but also to ensure donor parent IRBB7 has carrying this resistant gene. Three Malaysia commercial varieties, MR219, MR220CL and MR263 were also being included in this screening process to strengthen the outcome result. The disease symptom starts appeared after 3 days inoculation. Symptoms of water soaking up to yellow stripes on the affected blades were observed, Then, the necrotic lesion starting from the leaf tips and gradually increase in length and width with wavy margin. This result is similar as was reported by Chen et al. (2008), Khan et al. (2015) and Majumder et al. (2020). In our finding, all three commercial varieties, MR219, MR220CL2 and MR263 were classified as susceptible because lesion length recorded above $10 \mathrm{~cm}$ after 25 days inoculation. This result was in line with Chukwu et al. (2019) reported that there were no commercial varieties found to be resistant against the disease. The donor parent IRBB7, by contrast, has low incidence of BLB disease symptom. The lesion length of affected leaves was maintained $<5 \mathrm{~cm}$ even after 25 days inoculation. This has proved IRBB7 was confirmed carrying $X a 7$ gene and has resistant characteristic. Two STS marker namely, ID7 and ID15 were used to tag Xa7 gene in donor parent IRBB7. Result from marker analysis shows both markers have polymorphic characters. This describe that the marker has link with Xa7 gene and similar with Zhang et al. (2009) finding. Therefore, it can be used in any breeding program for development of resistant varieties.

The elite rice variety, MR219 was chosen in this present project as a recurrent parent because it is the most popular high yielding rice variety in Malaysia (Miah et al. 2015). To further improve this variety particularly to enhance BLB disease resistance, marker-assisted backcrossing approach was adopted. This approach was found to be effective to recover all good characters of MR219. Moreover, this approach could eliminate undesirable traits from donor parent. After three cycles of backcrossing, approximately $90 \%$ similarity of MR219 characters was obtained. Selfing was conducted for another three seasons to generate homozygote and uniform progenies. Selection using MAS application was conducted in each generation and therefore, the presence of $X a 7$ gene is guaranteed. The $X a 7$ gene was tagged by two similar SSR flanking markers in earlier experiment. All of individuals or lines without this Xa7 gene were discarded. At the stage of $\mathrm{BC}_{3} \mathrm{~F}_{4}$, finally we managed to generate 19 lines with homozygous Xa7 gene.

Evaluation of similarity and agronomic performance of the 19 lines with recurrent parent MR219 and IRBB7 was conducted together with two $\mathrm{BC}_{3} \mathrm{~F}_{4}$ lines without $\mathrm{Xa7}$ gene as check variety. Findings revealed that amongst the nine evaluation traits, only six characters were found to be significant different between donor IRBB7 and MR219. Recurrent parent MR219 was significantly higher in plant height, shorter flag leaf, longer flowering and maturity date, longer panicle length and better yield. This explained that MR219 contained better character than IRBB7 except for the flag leaf length and flowering and maturity date. All the 19 lines including two check lines were high recovery to MR219 with better improvement. Semi-dwarf (plant height of 90 to $100 \mathrm{~cm}$ ), longer flag leaf, early flowering and maturation, longer panicle length, moderate total number of tiller (to avoid senescence tillers) and dense number of productive spikelet for better yield are the characteristics have been considered as important selection criteria in rice breeding for the development of new varieties, apart for durable disease resistant. These traits are crucial to contribute significantly to increase rice yield (Fatimah et al., 2014; Hasanah et al., 2017; Rahman et al., 2014). Such result as was expected because similarity among $\mathrm{BC} 3$ population was $90 \%$ with recurrent parent (MR219). This finding was in line with Wu et al. (2004), whereby genetic similarity among $\mathrm{BC}_{3}$ population of recurrent parent, Vandana were above $85 \%$.

Disease parameter lesion length were found to be very excellent results. Upon artificial disease inoculation, the recurrent parent, MR219 and positive control, MR263 were found to be affected with $>15 \mathrm{~cm}$ lesion length which indicating susceptible. Whereas, findings on 19 lines showed that all the 19 introgression Xa7 lines were resistant towards Xoo infection. The results strongly confirmed that the $X a 7$ gene inherited have resistant characteristics. Chen et al. (2008) reported that Xa7 gene provide dominant resistance against BLB pathogen. Among the most potential introgressed lines obtained from the present study were PB-2-107 and PB-2-34. These potential lines were selected because they produced the yield much more superior than MR219 and showed other good agronomic characteristics such as plant height and maturity date which are slightly shorter and earlier than recurrent parent, MR219. The development of the improved resistant lines will further broaden the genetic resource base of rice and eventually assist further research aimed at increasing the local production of rice. As a contribution to knowledge, 
this is the first report on successful introgression of BLB resistant gene, Xa7 into elite rice MR219 noted for its high yielding potential in Malaysia.

\section{Conclusion}

This study has proved that $\mathrm{Xa7}$ gene showed resistant characteristic against Xoo-severe strain. This study demonstrated that Xa7 gene was introgressed by markerassisted backcrossing into elite rice, MR219. Newly improved lines, PB-2-107 and PB-2-34 showed outstanding performances in both agronomic and disease resistance assessments.

\section{Acknowledgements}

Special acknowledgements to Ministry of Energy, Science, Technology, Environment and Climate Change Research \& Development Fund (MESTECC R\&D Fund) with grant numbers of TF FP0214B055 (DSTIN) and Malaysian Agricultural Research and Development Institute (MARDI) staffs for supporting of all research activities.

\section{References}

BHANDARI, G., 2014. An overview of agrochemicals and their effects on environment in Nepal. Applied Ecology and Environmental Sciences, vol. 2, no. 2, pp. 66-73. http://dx.doi.org/10.12691/ aees-2-2-5.

CHEN, S., HUANG, Z., ZENG, L., YANG, J., LIU, Q. and ZHU, X., 2008. High-resolution mapping and gene prediction of xanthomonas oryzae pv. oryzae resistance gene Xa7. Molecular Breeding, vol. 22, no. 3, pp. 433-441. http://dx.doi.org/10.1007/s11032-008-9187-1.

CHEN, S., LIN, X.H., XU, C.G. and ZHANG, Q.F., 2000. Improvement of bacterial blight resistance of 'Minghui 63', an elite restorer line of hybrid rice, by molecular marker-assisted selection. Crop Science, vol. 40, pp. 239-244.

CHUKWU, S.C., RAFII, M.Y., RAMLEE, S.I., ISMAIL, S.I., HASAN, M.M., OLADOSU, Y.A., MAGAJI, U.G., AKOS, I. and OLALEKAN, K.K., 2019. Bacterial leaf blight resistance in rice: a review of conventional breeding to molecular approach. Molecular Biology Reports, vol. 46, no. 1, pp. 1519-1532. http://dx.doi.org/10.1007/ s11033-019-04584-2. PMid:30628024.

ELIXON, S., ASFALIZA, R., OTHMAN, O., SITI NORSUHA, M., MAISARAH, M.S., ALICIA, J. and SHAHIDA, H., 2017. Evaluation on yield, yield component and physico-chemicals of advanced rice lines. Journal of Tropical Agriculture and Food Science, vol. 45, no. 2, pp. 131-143.

FATIMAH, F., PRASETIYONO, J., DADANG, A. and TASLIAH, T., 2014. Improvement of early maturity in rice variety by marker assisted backcross breeding of $\mathrm{Hd} 2$ gene. Indonesian Journal of Agricultural Science, vol. 15, no. 2, pp. 55-64. http://dx.doi. org/10.21082/ijas.v15n2.2014.p55-64.

HASAN, M.M., RAFI, M.Y., ISMAIL, M.R., MAHMOOD, M., RAHIM, H.A., ALAM, M.A., ASHKANI, S., MALEK, M.A. and LATIF, M.A., 2015. Marker-assisted backcrossing: a useful method for rice improvement. Biotechnology, Biotechnological Equipment, vol. 29, no. 2, pp. 237-254. http://dx.doi.org/10.1080/13102818.20 14.995920. PMid:26019637.
HASANAH, N., SADARUDDIN, S. and SUNARYO, W., S., 2017. Yieldrelated traits characterization of local upland rice cultivars originated from East and North Kalimantan, Indonesia. Biodiversitas, vol. 18, no. 3, pp. 1165-1172. http://dx.doi. org/10.13057/biodiv/d180339.

INTERNATIONAL NETWORK FOR GENETIC EVALUATION OF RICE INGER, 1996. Standard evaluation system for rice. Philippines: INGER.

INTERNATIONAL RICE RESEARCH INSTITUTE - IRRI, 1988. Standard evaluation system for rice. Philippines: University of Los Banos/IRRI.

INTERNATIONAL RICE RESEARCH INSTITUTE - IRRI, 2013 [viewed 3 February 2021]. World rice statistics 2013 [online]. Available from: http://irri.org/index.php?option=com k2\&view=item \&id=9081\& Itemid=100481 \&lang=en

JI, Z., WANG, C. and ZHAO, K., 2018. Rice routes of countering Xanthomonas oryzae. International Journal of Molecular Sciences, vol. 19, no. 10, pp. 3008. http://dx.doi.org/10.3390/ijms19103008. PMid:30279356.

JIANG, N., YAN, J., LIANG, Y., SHI, Y., HE, Z., WU, Y., ZENG, Q., LIU, X. and PENG, J., 2020. Resistance genes and their interactions with bacterial blight/leaf streak pathogens (Xanthomonas oryzae) in rice (Oryza sativa L.): an updated review. Rice, vol. 13, no. 1, pp. 3. http://dx.doi.org/10.1186/s12284-019-0358-y.

KHAN, J.A., ARSHAD, H.M., SALEEM, K., SANDHU, A.F., HASNAIN, S. and BABAR, M.M., 2012. Evaluation of resistance genes in rice against local isolates of Xanthomonas oryzae pv. oryzae in Punjab Province of Pakistan. Archiv für Phytopathologie und Pflanzenschutz, vol. 45, no. 15, pp. 1826-1839. http://dx.doi.or $\mathrm{g} / 10.1080 / 03235408.2012 .712830$.

KHAN, M.W., ABBASI, F.M., MASOOD, M.S., RABBANI, A., ABBASI, M.F., SAJID, M., KHAN, U., AHMAD, H., 2015. Identification of bacterial blight resistance gene Xa7 in rice (Oryzae sativa L.) through STS marker. International Journal of Biosciences, vol. 6 , no. 2, pp. 318-324. http://dx.doi.org/10.12692/ijb/6.2.318-324.

KHAZANAH RESEARCH INSTITUTE - KR INSTITUTE. (2019). The status of the paddy and rice industry in Malaysia. Kuala Lumpur: KR Institute.

LINDENTHAL, M., STEINER, U., DEHNE, H.W. and OERKE, E.C., 2005. Effect of downy mildew development on transpiration of cucumber leaves visualized by digital infrared thermography. Phytopathology, vol. 95, no. 3, pp. 233-240. http://dx.doi. org/10.1094/PHYTO-95-0233. PMid:18943115.

MAJUMDER, K., MONDAL, S.I., MALLICK, R. and DASGUPTA, T., 2020. Identification of BLB resistant genes in some rice varieties for development of high yielding bacterial leaf blight tolerant types. Journal of Environmental Biology, vol. 41, pp. 85-91.

MAJUMDER, K., MONDAL, S.J., MALLICK, R. and DASGUPTA, T., 2019. Identification of BLB resistant genes in some rice varieties for development of high yielding bacterial leaf blight tolerant types. Journal of Environmental Biology, vol. 41, no. 1, pp. 86-91.

MEW, T.W., CRUZ, V. and REYES, R.C., 1982. Interaction of Xanthomonas campestris pv. oryzae and a resistant rice cultivar. Phytopathology, vol. 72, no. 7, pp. 786-789. http://dx.doi. org/10.1094/Phyto-72-786.

MIAH, G., RAFII, M.Y., ISMAIL, M.R., PUTEH, A.B., RAHIM, H.A. and LATIF, M.A., 2015. Recurrent parent genome recovery analysis in a marker-assisted backcrossing program of rice (Oryza sativa L.). Comptes Rendus Biologies, vol. 338, no. 2, pp. 83-94.

NODA, T., LI, C., LI, J., OCHIAI, H., ISE, K. and KAKU, H., 2001. Pathogenic diversity of Xanthomonas oryzae pv. oryzae strains from Yunnan province, China. Japan Agricultural Research Quarterly, vol. 35, no. 2, pp. 97-103. http://dx.doi.org/10.6090/jarq.35.2. 
OGAWA, T., BUSTO, G., TABIEN, R., ROMERO, G., ENDO, N. and KHUSH, G.S., 1991. Grouping of rice cultivars based on reaction pattern to Philippine races of bacterial blight pathogen (Xanthomonas campestris pv. oryzae). Ikushugaku Zasshi, vol. 41, no. 1, pp. 109119. http://dx.doi.org/10.1270/jsbbs1951.41.109.

PRIOUL, J.-L., QUARRIE, S., CAUSSE, M. and DE VIENNE, D., 1997. Dissecting complex physiological functions through the use of molecular quantitative genetics. Journal of Experimental Botany, vol. 48, no. 6, pp. 1151-1163. http://dx.doi.org/10.1093/ jxb/48.6.1151.

RAHMAN, M.A., HAQUE, M.E., SIKDAR, B., ISLAM, M.A. and MATIN, M.N., 2014. Correlation analysis of flag leaf with yield in several rice cultivars. Journal of Life and Earth Science, vol. 8, pp. 49-54. http://dx.doi.org/10.3329/jles.v8i0.20139.

SAHA, S., GARG, R., BISWAS, A. and RAI, A.B., 2015. Bacterial diseases of rice: an overview. Journal of Pure \& Applied Microbiology, vol. 9, no. 1, pp. 725-736.

SHAMSUDIN, H.S., MUHAMMAD YAMAN, M.A., AHMAD, A. and NOOR HASSIM, M.F., 2019. Elucidating the dynamic of drought tolerance rice, MR219-4 to the Xanthomonas oryzae infection. Malaysian Applied Biology, vol. 48, no. 1, pp. 157-162.

SHAMSUDIN, N.A., SWAMY, B.P., RATNAM, W., STA. CRUZ, M.T., RAMAN, A. and KUMAR, A., 2016. Marker assisted pyramiding of drought yield QTLs into a popular Malaysian rice cultivar, MR219. BMC Genetics, vol. 17, pp. 30. http://dx.doi.org/10.1186/ s12863-016-0334-0. PMid:26818269.

SIDHU, G.S., KHUSH, G.S. and MEW, T.W., 1978. Genetic analysis of bacterial blight resistance in seventy-four cultivars of rice, Oryza sativa L. Theoretical and Applied Genetics, vol. 53, no. 3, pp. 105-111. http://dx.doi.org/10.1007/BF00272687. PMid:24311342.

SIWAR, C., IDRIS, N.D., YASAR, M. and MORSHED, G., 2014. Issues and challenges facing rice production and food security in the granary areas in the east coast economic region (ECER), Malaysia. Research Journal of Applied Sciences, Engineering and Technology, vol. 7, no. 4, pp. 711-722. http://dx.doi.org/10.19026/rjaset.7.307.
TAGAMI, Y. and MIZUKAMI, T. (1962). Historical review of the researches on bacterial leaf blight of rice caused by Xanthomonas oryzae (Uyeda et Ishiyama) Dowson. Tokyo: Plant protection Division, Ministry of Agriculture and Forestry, 112 p. Special Report of the Plant Diseases and Insect Pests Forecasting Service, no. 10.

UNITED STATES DEPARTMENT OF AGRICULTURE - USDA. (2020). Global market analysis: world agricultural production. Washington: USDA, 33 p.

VERA CRUZ, C.M., BAI, J., ONA, I., LEUNG, H., NELSON, R.J., MEW, T.W. and LEACH, J.E., 2000. Predincting durability of a disease resistance gene based on an assessment of the fitness loss and eidemiological consequences of avirulence gene mutation. Proceedings of the National Academy of Sciences of the United States of America, vol. 97, no. 25, pp. 13500-13505. http://dx.doi. org/10.1073/pnas.250271997. PMid:11095723.

WEBB, K.M., ONA, I., BAI, J., GARRETT, K.A., MEW, T., VERA CRUZ, C.M. and LEACH, J.E., 2010. A benefit of high temperature: increased effectiveness of a rice bacterial blight disease resistance gene. The New Phytologist, vol. 185, no. 2, pp. 568-576. http://dx.doi. org/10.1111/j.1469-8137.2009.03076.x. PMid:19878463.

WU, J.L., SINHA, P.K., VARIAR, M., ZHENG, K.L., LEACH, J.E., COURTOIS, B. and LEUNG, H., 2004. Association between molecular markers and blast resistance in an advanced backcross population of rice. Theoretical and Applied Genetics, vol. 108, no. 6, pp. 1024-1032. http://dx.doi.org/10.1007/s00122-003-1528-1. PMid:15067388.

WURFF, A.V., STREMINSKA, M. and ELINGS, A. (2016). Interactions among rice-Xanthomonas-Rhizoctonia and biostimulants. Wageningen: Greenhouse Horticulture.

ZHANG, Y., WANG, J., PAN, J., GU, Z., CHEN, X., JIN, Y., LIU, F., ZHANG, H. and MA, B., 2009. Identification and molecular mapping of the rice bacterial blight resistance gene allelic to Xa7 from an elite restorer line Zhenhui 084. European Journal of Plant Pathology, vol. 125, no. 2, pp. 235. http://dx.doi.org/10.1007/ s10658-009-9478-3. 